\title{
THE IMPLEMENTATION OF INDONESIA HEALTH MINISTER REGULATION RELATED TO STERILIZED DISPENSING IN "X" HOSPITAL IN GIANYAR-BALI
}

\author{
Ni Luh Putu Lestari Dewi ${ }^{1 *}$, Ni Made Ari Ginarsih ${ }^{1}$, I Made Agus Gelgel Wirasuta ${ }^{1}$ \\ ${ }^{1}$ Department of Pharmacy, Faculty of Math and Science, Udayana University \\ Corresponding author email: putulestaridw@gmail.com
}

\begin{abstract}
Background: The application of Regulation of the Minister of Health Number 72 of 2016 is very important to be implemented in every Pharmacy Installation in a hospital, one of which is in the clinical pharmacy service section, namely dispensing sterile preparations to avoid the possibility of medication errors. Objective: The research aimed to find out how the implementation of Regulation of the Minister of Health Number 72 of 2016 stipulated in the basic guidelines of aseptic techniques related to space, equipment, and the implementation of dispensing sterile preparations with its practice in Hospital "X" Gianyar, Bali. Methods: This research used Sequential Explanatory design by combining quantitative and qualitative methods. Results: The results of quantitative research with a checklist found the percentage of completeness of the room and equipment by $100 \%$, while the conformity of the practice with the guidelines of $76.48 \%$ is appropriate. The results of qualitative research with triangulation matrices that practice is by the guidelines. Conclusion: Dispensing sterile preparations at the Hospital " $\mathrm{X}$ " is following the basic guidelines of aseptic techniques that refer to Regulation of the Minister of Health Number 72 of 2016.
\end{abstract}

Keywords: Implementation, regulation, dispensing, sterile preparations, guidelines, medication errors

\section{INTRODUCTION}

Pharmaceutical workers as one of the permanent staff requirements in hospital HR whose overall work will be regulated and determined by standards, which are regulated in Minister of Health Regulation No. 72 of 2016 concerning Pharmaceutical Services Standards in Hospitals. Based on pasal 3 ayat (3) point $j$, it is stated that one part of clinical pharmacy services is sterile preparation dispensing. Then the pasal 3 ayat (4) mentions clinical pharmacy services in the form of dispensing sterile preparations as referred to in pasal 3 ayat (3) point $\mathrm{j}$ may only be carried out by hospitals that have the means to produce sterile preparations. Further, the requirements regarding dispensing of sterile preparations in the Minister of Health Regulation No. 72 of 2016 are listed in Appendix Chapter III on Clinical Pharmacy Services 10th point. In dispensing sterile preparations, which is one of the pharmaceutical works, Pharmacists must establish standard operating procedures (SOP). Appendix Chapter III point 10 continues that the technical instructions regarding dispensing of sterile preparations in hospitals are further regulated by the DirectorGeneral. ${ }^{[1]}$ This technical guideline has been contained in the Basic Guidelines for Aseptic Engineering compiled by the Directorate of Community Pharmacy and Clinical Development, the Directorate 
General of Pharmaceutical and Medical Devices Development, Ministry of Health Republic of Indonesia in 2009.

Based on the Guidelines of Aseptic Technique Basic, dispensing sterile preparations is a series of changes in the shape of the drug from its original condition into a new product by the process of dissolving or adding other ingredients aseptically carried out by pharmacists in health care facilities. ${ }^{[2]}$ Special concerns in the dispensing of sterile preparations in hospitals include the requirements for special rooms and equipment, procedures for storing sterile preparations according to the guidelines, and steps for dispensing sterile preparations aseptically, each step, under SOP. The dispensing process requires a special and controlled room consisting of a preparation room, a washing room, a dressing room, an intermediate room, and a sterile room that must meet certain special requirements. The layout of the sterile room must also follow the guidelines to facilitate the flow of implementation. In addition to the room, the equipment must also be complete and by the guidelines, including personal protective equipment (PPE) consisting of protective clothing, gloves, protective glasses, disposable masks; and laminar airflow (LAF) which consists of two types according to their respective functions, namely horizontal airflow, and vertical airflow. ${ }^{[2]}$

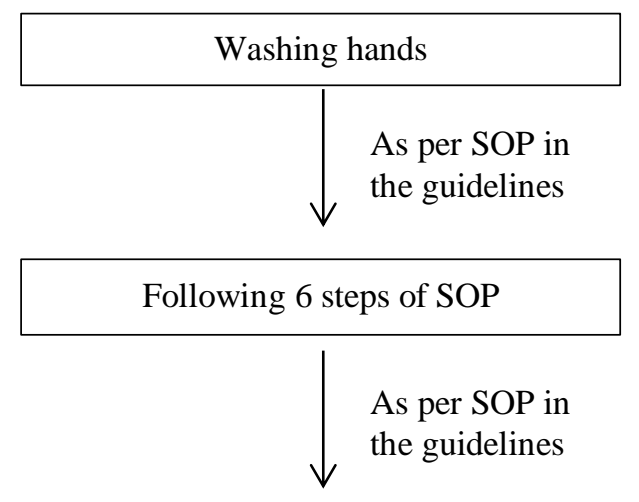

\footnotetext{
Put in the substance through pass box

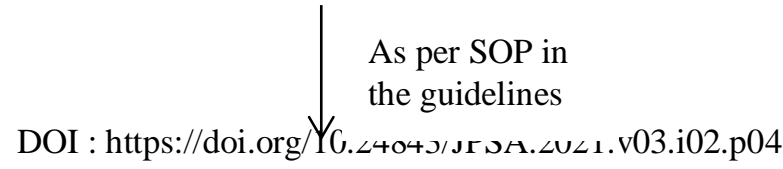

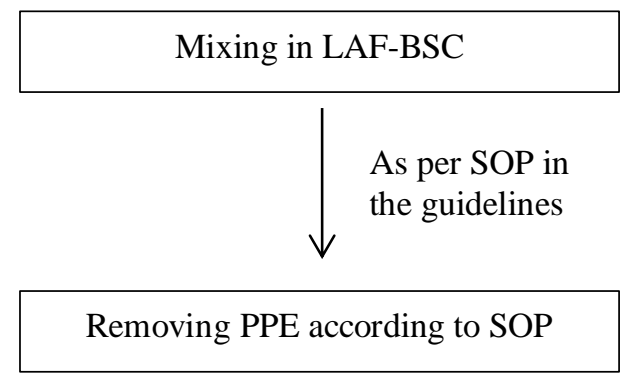

Figure 1. Flowchart flow steps for dispensing sterile preparations in a hospital as stated in the Aseptic Technical Basic Guidelines. ${ }^{[2]}$

The procedure for storing non-cytostatic sterile preparations based on the Guidelines of Aseptic Technical Basic after mixing depends on the stability of each component of the drug. Two special conditions are important to consider in this storage process, namely exposure to light and storage temperature. Where sterile preparations that have been formulated are kept protected from direct light, using carbon paper or black plastic bags or aluminium foil, storage temperature ranges from $2^{\circ} \mathrm{C}-8^{\circ} \mathrm{C}$, can be stored in the refrigerator but not in the freezer. ${ }^{[2]}$

Large hospitals that have completed and accredited facilities mostly have completed sterile room facilities for the implementation of the aseptic technique sterile dispensing process. Hospitals that have been equipped with these facilities certainly provide chemotherapy services because one of the types of aseptic dispensing activities is the handling of cytostatic preparations. In addition to cytostatic preparations, other related activities include mixing injection drugs and preparing parenteral nutrition. Hospital " $\mathrm{X}$ " is a class B hospital in Gianyar Regency, Bali Province, which provides complete facilities for dispensing sterile aseptic techniques. Hospital " $\mathrm{X}$ " is known for having complete facilities and services, accompanied by reliable human resources in their respective fields. It is 
very important for pharmacists and pharmaceutical technical personnel who work on dispensing sterile preparations to carry out their work under the basic guidelines for aseptic dispensing.

Based on the attachment of Chapter III Clinical Pharmacy Services in the Minister of Health Regulation No. 72 of 2016, dispensing of sterile preparations must be carried out in aseptic pharmaceutical installations to ensure that patients receive drugs according to the required dosage; guarantee the stability and sterility of a product; protect officers from exposure to hazardous substances, and avoid medication errors. ${ }^{[1]}$ Pharmacists must be competent in implementing science and regulations related to the process of dispensing sterile preparations in hospitals so that errors do not occur due to implementation that is not by the guidelines or SOP. This research explained the implementation of the provision of sterile preparations at " $\mathrm{X}$ " hospital in Gianyar, Bali.

\section{RESEARCH METHODS}

This research applied a combination method with Sequential Explanatory research design, which means combining quantitative methods with qualitative methods so that they can be used together. Quantitative research methods were carried out using a checklist method of conformity between sterile space requirements and SOPs in the Basic Guidelines for Aseptic Techniques by the Directorate of Community Pharmacy and Clinical Development with pharmacist practices in the Pharmacy Installation Unit of the Hospital "X" in Gianyar, Bali. The results are presented in the form of a percentage stating the completeness of the room and equipment, as well as the suitability of the practice of dispensing sterile preparations using the following equation:

$$
\%=\frac{\text { completeness total } / \text { suitability }}{\text { number of criteria observed }}
$$

While the qualitative research method was carried out by observation and in-depth interviews with the pharmacist responsible for the dispensing of sterile preparations at the "X" hospital, the information obtained was linked to related documents, then presented in the form of a triangulation matrix.

\section{RESULTS AND DISCUSSION Results of Quantitative Research}

Research conformity checklist dispensing sterile dosage activity in " $\mathrm{X}$ " hospital on the SOP on Basic Guidelines Aseptic technique in the form of checklist completeness rooms and equipment as well as the suitability of each step checklist process.

Table 1. The results of the checklist for completeness of room facilities for mixing sterile preparations based on the Basic Guidelines for Aseptic Technique at " $X$ " Hospital

\begin{tabular}{lccc} 
& \multirow{2}{*}{ Types of Room Facilities } & \multicolumn{2}{c}{ Completeness } \\
\cline { 2 - 3 } & Yes & No \\
\hline Preparation Room & $\sqrt{ }$ & - \\
\hline Handwashing Room & $\sqrt{ }$ & - \\
\hline Changing room & $\sqrt{ }$ & - \\
\hline Space between & & - \\
\hline Sterile room with the following conditions: & & \\
Particles $0,5 \mu<350.000$ particles, microorganisms $<100 / \mathrm{m}^{3}$ air, temperature $18-$ & & \\
$22^{\circ} \mathrm{C}$, humidity $35-50 \%$, there is a HEPA filter, indoor air pressure is more positive \\
than outside, pass box between the preparation room \& sterile room
\end{tabular}


Table 2. The results of the checklist for the completeness of equipment facilities for mixing sterile preparations based on the Basic Guidelines for Aseptic Technique at " $\mathrm{X}$ " Hospital

\begin{tabular}{|c|c|c|}
\hline \multirow[b]{2}{*}{ Kinds of Equipment } & \multicolumn{2}{|c|}{ Completeness } \\
\hline & Yes & No \\
\hline \multicolumn{3}{|l|}{ Personal Protective Equipment (PPE) consists of : } \\
\hline Shield clothing & $\sqrt{ }$ & - \\
\hline Latex Gloves & $\sqrt{ }$ & - \\
\hline Protective glasses & $\sqrt{ }$ & - \\
\hline Disposable mask & $\sqrt{ }$ & - \\
\hline Cap (Head Cover) & $\sqrt{ }$ & - \\
\hline Shoe Covers & $\sqrt{ }$ & - \\
\hline Boots & $\sqrt{ }$ & - \\
\hline \multicolumn{3}{|l|}{ Laminar Air Flow (LAF) consists of : } \\
\hline Horizontal LAF & $\sqrt{ }$ & - \\
\hline Vertical LAF & $\sqrt{ }$ & - \\
\hline Total Percentage (\%) Completeness & $100 \%$ & $0 \%$ \\
\hline
\end{tabular}

Table 3. The results of a checklist of steps for mixing aseptic sterile preparations based on the Basic Guidelines for Aseptic Techniques at " $X$ " Hospital

\begin{tabular}{|c|c|c|}
\hline \multirow[b]{2}{*}{ Steps according to SOP } & \multicolumn{2}{|c|}{ Suitability } \\
\hline & Suitable & Not Suitable \\
\hline \multicolumn{3}{|l|}{ WASHING HANDS } \\
\hline Wet your hands with clean running water & $\sqrt{ }$ & - \\
\hline Use antiseptic soap & $\sqrt{ }$ & - \\
\hline Palms, fingers, nails rubbed in 20 seconds & - & $\sqrt{ }$ \\
\hline Rinse hands with running water for 10 seconds & - & $\sqrt{ }$ \\
\hline Cover the faucet with a clean lap cloth /with-elbows & - & $\sqrt{ }$ \\
\hline Dry your hands with a clean cloth & $\sqrt{ }$ & - \\
\hline \multicolumn{3}{|l|}{ USING PERSONAL PROTECTIVE EQUIPMENT (PPE) } \\
\hline $\begin{array}{l}\text { Take off your usual clothes, shoes, jewellery, save or hand them over to the } \\
\text { officer. }\end{array}$ & $\sqrt{ }$ & - \\
\hline Wash hands, arms, elbows, feet with disinfectant & $\sqrt{ }$ & - \\
\hline Dry your hands with an automatic electric dryer & $\sqrt{ }$ & - \\
\hline The hair is covered with stamps and put into clothes & $\sqrt{ }$ & - \\
\hline Masks covering nose, mouth, beard & $\sqrt{ }$ & - \\
\hline The whole leg is covered with leg cover, then tied & $\sqrt{ }$ & - \\
\hline Wear trousers tucked into the leg cover & $\sqrt{ }$ & - \\
\hline The sleeve is tucked into the glove & $\sqrt{ }$ & - \\
\hline Gloves moistened with disinfectant $/ 70 \%$ alcohol & $\sqrt{ }$ & - \\
\hline Use the last protective glasses & $\sqrt{ }$ & - \\
\hline \multicolumn{3}{|l|}{ ENTERING MATERIALS THROUGH PASS BOX } \\
\hline Clean the pass box according to fixed procedures & $\sqrt{ }$ & - \\
\hline $\begin{array}{l}\text { Open the pass box door from outside the sterile room (make sure the pass } \\
\text { box in the sterile room is closed) }\end{array}$ & $\sqrt{ }$ & - \\
\hline Insert the tools \& ingredients, then close the pass box door & $\sqrt{ }$ & - \\
\hline $\begin{array}{l}\text { Open the pass box door from a sterile room (make sure the pass box outside } \\
\text { the sterile room is closed) }\end{array}$ & $\sqrt{ }$ & - \\
\hline Tools \& materials are removed from the pass box carefully & $\sqrt{ }$ & - \\
\hline \multicolumn{3}{|l|}{ MIXING IN LAF-BSC } \\
\hline Connect LAF to the power source ( 220 volts) & $\sqrt{ }$ & - \\
\hline Blowers \& UV are turned on at least 15 min before & - & $\sqrt{ }$ \\
\hline Turn off the UV light & $\sqrt{ }$ & - \\
\hline Open the LAF shutter door, place it horizontally on the table & $\sqrt{ }$ & - \\
\hline Clean the LAF surface with $70 \%$ alcohol & - & $\sqrt{ }$ \\
\hline Tools and ingredients to be added to LAF are wiped with $70 \%$ alcohol & - & $\sqrt{ }$ \\
\hline Tools and materials are placed in LAF according to their layout & $\sqrt{ }$ & - \\
\hline
\end{tabular}




\begin{tabular}{lcc}
\hline \multicolumn{1}{c}{ Steps according to SOP } & \multicolumn{2}{c}{ Suitability } \\
\cline { 2 - 3 } & Suitable & Not Suitable \\
\hline Left for 5 minutes & - & $\sqrt{ }$ \\
\hline REMOVAL OF PROTECTIVE EQUIPMENT (PPE) & & \\
\hline Remove the outer gloves according to the fixed procedure & - & - \\
\hline Remove protective clothing according to fixed procedures & $\sqrt{ }$ & - \\
\hline Take off the headgear and gloves inside and throw it into a closed bag & $\sqrt{ }$ & - \\
\hline Place the bag in the remaining waste container & $\sqrt{ }$ & - \\
\hline Wash your hands according to SOP & $76,48 \%$ & $23,52 \%$ \\
\hline Amount Percentage (\%) Compliance & & \\
\hline
\end{tabular}

Table 4. Triangulation matrix about the availability of sterile preparation dispensing facilities at " $\mathrm{X}$ " Hospital

\begin{tabular}{|c|c|c|c|}
\hline Topic & Interview & Document & Triangulation Analysis \\
\hline $\begin{array}{l}\text { Availability of } \\
\text { Facility }\end{array}$ & $\begin{array}{l}\text { The complete sterile preparation } \\
\text { dispensing facilities at "X" } \\
\text { Hospital are provided to support } \\
\text { pharmaceutical services, both for } \\
\text { inpatients and outpatients } \\
\text { (parenteral nutrition, injection, }\end{array}$ & $\begin{array}{lr}\text { Every year } \\
\text { routine data } \\
\text { collection on } \\
\text { facilities (rooms, } \\
\text { equipment) }\end{array}$ & $\begin{array}{l}\text { The availability of sterile } \\
\text { dispensing facilities at "X" Hospital } \\
\text { for pharmacy services to patients so } \\
\text { that each year routinely is recorded } \\
\text { facilities (rooms, equipment) that } \\
\text { must be equipped or replaced }\end{array}$ \\
\hline
\end{tabular}

Table 5. Triangulation matrix concerning the implementation of dispensing sterile preparations at " $\mathrm{X}$ " Hospital

\begin{tabular}{llll}
\multicolumn{1}{c}{ Topic } & \multicolumn{1}{c}{ Interview } & \multicolumn{1}{c}{ Document } & \multicolumn{2}{c}{ Triangulation Analysis } \\
\hline Sterile & Dispensing sterile preparations at & There are sterile & Dispensing sterile preparations at \\
preparation & "X" Hospital is carried out by & SOP dispensing "X" Hospital is done by \\
dispensing & pharmacists who are assisted by & documents & pharmacists and TTK according to \\
& TTK in a special room with & & SOP documents to avoid \\
& complete equipment and work & & medication errors \\
& $\begin{array}{l}\text { steps according to SOP; although } \\
\text { sometimes there are still small }\end{array}$ & & \\
& steps that are missed & & \\
\hline
\end{tabular}

\section{Results of Qualitative Research}

Based on in-depth interviews with the responsible pharmacist in the sterile dispensing section, the results are presented in the triangulation matrix in the following table, shown in Table 4 and Table 5.

\section{DISCUSSION}

Based on the results of quantitative and qualitative research conducted to determine the completeness of the facilities and the suitability of the implementation of dispensing sterile preparations with SOPs at "X" Hospital judging from the aspect of the completeness of the facilities in the form of a room, the process of dispensing sterile preparations at " $\mathrm{X}$ " Hospital is classified as complete. This can be seen from the results of quantitative research in Table 1. which states the percentage of completeness is $100 \%$ following the regulation, namely Regulation of the Minister of Health No. 72 of 2016 pasal 3 ayat (4) states that clinical pharmacy services in the form of dispensing sterile preparations as referred to in pasal 3 ayat (3) point $\mathrm{j}$ can only be carried out by hospitals that have the means to produce sterile preparations. ${ }^{[1]}$

Furthermore, as contained in the attachment to Chapter III and contained in the Basic Guide to the Aseptic Technique, a special and controlled room is required for the mixing or dispensing process of this sterile preparation. Each component of the room is important because it has its role, including (1) the preparation room is used 
to carry out the administrative process and the preparation of medical devices and medicinal materials related to etiquette, labelling, calculation of dosage and volume of fluid; (2) handwashing rooms and changing clothes which are divided into first and second changing rooms with different conditions to use the complete PPE; (3) the intermediate space which is the room before the officer enters the sterile room; (4) sterile room with all the requirements in Table 1. is the central place for Pharmacists and TTK (pharmaceutical technical personnel) to carry out the mixing or dispensing activities of this sterile preparation. ${ }^{[2]}$ Based on research by Stucki (2008); Allen (2009); Austin (2009), if compounding is done in a room that is not by these standards, contamination is most likely. Compounding carried out at LAF in a sterile room or a suitable special room can prevent microbial contamination in compounding sterile preparations significantly compared to preparations that are formulated outside these criteria. ${ }^{[3],[4],[5]}$

In addition to space, facilities, and infrastructure in the form of equipment for dispensing sterile preparations at " $\mathrm{X}$ " Hospital also show the percentage of completeness of $100 \%$ in Table 2. The availability of complete equipment that meets these requirements is no less important; for example, the completeness of PPE is very important because of the safety of officers and maintaining the sterility of prepared preparations. ${ }^{[6]}$ Considering that the "X" Hospital has cancer patients with special mixed drug requirements so that if the officer does not use a complete PPE, then the possibility of contamination is high, which will endanger the health of officers and can reduce the sterility of the preparation.

Each PPE component has its provisions or conditions under the basic guidelines of aseptic techniques, including (1) complete protective clothing made of a material that is not translucent, does not release fabric fibres, long sleeves cuffed and closed at the front; (2) latex ( free powder ) gloves that are long enough to cover the wrist with minimal permeabilities; (3) protective glasses which are only used when handling cytostatic preparations; and (4) disposable masks as a shield to avoid contamination of preparations to the respiratory system of officers. In addition to using PPE, dispensing sterile preparations must also be carried out under LAF and transferring sterile preparations between spaces also through a pass box. ${ }^{[2]}$

The availability of facilities in the form of equipment and equipment is also supported by a statement from the pharmacist responsible for dispensing sterile preparations during interviews related to the topic of facility availability in Table 4. The reason for the " $\mathrm{X}$ " Hospital is providing room facilities and equipment in accordance with the requirements of this regulation to complete pharmaceutical services for patients so that they are regularly collected every year. Paying attention to the room and equipment must be following the guidelines to be very important in dispensing sterile preparations. This is supported by Melviya's research (2018) on evaluating the compounding of sterile preparations at Semarang City's "X" Hospital which states that if infrastructure facilities and equipment are not under the guidelines, it is feared that it can increase the risk of microbial contamination when dispensing sterile preparations. ${ }^{[7]}$

$$
\text { General requirements for }
$$
compounding sterile preparations in the form of requirements for human resources, rooms, equipment, and place of compounding following the guidelines for dispensing sterile preparations made by the Ministry of Health of the Republic of Indonesia. This study compares the general requirements contained in these guidelines with the results of the checklist and observations at the "X" Gianyar Hospital. A summary of the results of this comparison can be seen in Table 6 . 


\begin{tabular}{|c|c|c|}
\hline Parameter & Requirements & Observation Results \\
\hline Human Resources & $\begin{array}{l}\text { Pharmacists and pharmaceutical } \\
\text { technical personnel }\end{array}$ & $\begin{array}{l}\text { Pharmacists and pharmaceutical technical } \\
\text { personnel }\end{array}$ \\
\hline $\begin{array}{l}\text { Compounding } \\
\text { room }\end{array}$ & $\begin{array}{l}\text { Consisting of the preparation room, } \\
\text { washing room, dressing room, } \\
\text { intermediate space, and sterile space }\end{array}$ & $\begin{array}{l}\text { Consisting of the preparation room, washing } \\
\text { room, dressing room, intermediate space, } \\
\text { and sterile space }\end{array}$ \\
\hline Equipment & $\begin{array}{l}\text { Complete protective clothing, gloves, } \\
\text { masks, protective glasses }\end{array}$ & $\begin{array}{l}\text { Complete protective clothing, gloves, masks, } \\
\text { protective glasses }\end{array}$ \\
\hline $\begin{array}{l}\text { Compounding } \\
\text { place }\end{array}$ & Laminar airflow (LAF) & $\begin{array}{l}\text { LAF - BSC (biological safety cabinet) type } \\
\text { II }\end{array}$ \\
\hline
\end{tabular}

Mixing sterile preparations requires special attention, especially on the protection of products from contamination of microorganisms, protection from officials and the environment against exposure, the stability of preparations as well as unmatched preparations. ${ }^{[2]}$ Contaminated sterile preparations can cause a high incidence of therapeutic errors in injection preparations ${ }^{[8]}$, especially for sterile preparations that require special preparation before use, such as reconstitution or dilution. ${ }^{[9]}$ Compounding sterile preparations should be carried out by pharmaceutical personnel, namely pharmacists, and assisted by pharmaceutical technical personnel ${ }^{[2]}$; this has been implemented by the "X" Hospital. In line with the Minister of Health Regulation No. 72 of 2016 concerning Pharmaceutical Services Standards in Hospitals, which states that compounding sterile preparations in hospitals is carried out by pharmacists. ${ }^{[1]}$ Other knowledge about drug dosage, the stability, and compatibility of sterile preparations are also well understood by pharmaceutical personnel so that this will support the quality of the sterile preparations produced.

In terms of the steps in the process, dispensing of sterile preparations in " $\mathrm{X}$ " Hospital is carried out under the SOP that refers to the Minister of Health Regulation No. 72 of 2016 contained in the appendix to Chapter III as contained in the Aseptic Technical Basic Guidelines. Based on the results of quantitative research in Table 3. show the compatibility between the implementation in Hospital "X" with the SOP on the regulations that govern the Basic Guidelines for Aseptic Technique referring to Minister of Health Regulation No. 72 of $2016.76 .48 \%$ of the steps for dispensing sterile preparations at " $\mathrm{X}$ " Hospital have been carried out in accordance with the SOP. The percentage is fairly high, where the remaining $23.52 \%$, which is not appropriate, is a technical problem, for example, related to the time taken to take a step that is under the details of the time in the SOP. Another problem is related to the use of cleaning fluid that is not appropriate or not following the SOP in the washing or cleaning process every time will move to do the next step. The implementation of dispensing sterile preparations at "X" Hospital was declared by the SOP because of the high percentage. It was also supported by interviews with the responsible pharmacist (Table 5.), which stated that dispensing of sterile preparations in "X" hospitals was carried out by pharmacists assisted by TTK in a special room with complete equipment and work steps following SOP.

Based on Melviya's research (2018), which examined the mixing of injecting drugs in Semarang City X Hospital showed that the suitability of compounding personnel and infrastructure was $100 \%$, but the procedure for mixing injection sterile preparations was not under the Guidelines for Mixing Syringes and Cytostatic Handling (2009), affect the quality of the sterile preparations produced. ${ }^{[7]}$ The same thing was also shown in Hidayanti's study 
(2017), wherein the implementation of dispensing sterile preparations at Hospital $\mathrm{X}$, there were still officers who mixed injecting drugs, not in the room they were supposed to, but still in inpatient outlet rooms by not using PPE such as masks and gloves. ${ }^{[10]}$ These things can, of course, pose a risk to the safety of the working person and the safety of the patient who receives it. So it is considered very important to carry out the process of dispensing sterile preparations on the facilities and infrastructure that have been determined by the guidelines, as well as the flow of the steps of its implementation are complete and following the SOP.

Government Regulation Number 51 the Year 2009 concerning Pharmaceutical Work, in pasal 23 ayat (1) states that in carrying out pharmaceutical work, Pharmacists must establish Standard Operating Procedures (SOP). Pasal 23 ayat (2) confirms that SOPs must be made by Pharmacists in writing and updated continuously according to the development of science and technology in the pharmaceutical field and the provisions of the legislation. ${ }^{[1]}$ Dispensing sterile preparations is one of the clinical pharmacy services in hospitals based on pasal 3 ayat (3) Regulation of the Minister of Health No. 72 of 2016. ${ }^{[1]}$ The implementation of this dispensing activity must be following the SOPs made by pharmacists in hospital service units. As well as the SOP that is made this must refer to the Standard of Pharmaceutical Services at the Hospital as outlined in the form of basic guidelines for aseptic techniques.

The effect of SOPs on preventing medication errors is very important. Medication errors are inaccuracies or failures in the treatment process or the use of drugs caused by many factors. This can cause a lot of harm to patients, but medication errors can be prevented and avoided. ${ }^{[12]}$ Medication errors can occur, one of them at the dispensing stage. In the Perwitasari study (2010), 3.66\% of medication errors occurred at the dispensing stage which was caused by improper or incompatible SOP and incomplete drug preparation. ${ }^{[13]}$ Salmani Research (2016), medication errors with a high incidence occur in injection treatments which are sterile preparations including wrong dosage $(7.9 \%)$, miscalculation of drugs $(6.4 \%)$, and wrong infusion due to errors when mixing (9.5\%). ${ }^{[14]}$ Based on Pandini's research (2016) about the mixing profile of injection sterile preparations at Cilacap Regional Hospital and Austin and Elia's (2009) research related to a metaanalysis of the risk of microbial contamination in aseptic sterile preparations can describe the risk of medication error if the process is not under the SOP. For example, if the compounding process of sterile preparations is not carried out under LAF, it is feared that it can increase the risk of microbial contamination of sterile preparations so that it will have an impact on the therapeutic effect given to patients who receive it, even at the risk of giving toxic effects to patients. Besides, if it does not comply with the SOP, it can have an impact on the safety of the officers. ${ }^{[15],[5]}$

\section{CONCLUSION}

The results showed that the room, equipment, and dispensing procedures for sterile preparations at the "X" Hospital Gianyar, Bali was by the Minister of Health Regulation No. 72 of 2016 contained in the Basic Guidelines for Aseptic Technique compiled by the Directorate General of Pharmaceutical and Medical Devices Republic of Indonesia Ministry of Health 2009.

\section{CONFLICT OF INTEREST}

All authors state that no financial or personal relationships with other people or organizations could inappropriately influence this paper. 


\section{ACKNOWLEDGMENT}

Thank you to all those who played a role and have helped in completing this research, namely the administration of the Pharmacy Study Program and the Faculty of Mathematics and Natural Sciences, Udayana University, who have assisted in arranging a research cover letter; as well as the management and the Head of Pharmacy Installation and staff at the " $\mathrm{X}$ " Hospital in Gianyar, Bali.

\section{REFERENCES}

1. Kemenkes RI. Peraturan Menteri Kesehatan Republik Indonesia Nomor 72 Tahun 2016 tentang Standar Pelayanan Kefarmasian di Rumah Sakit. Jakarta: Kementerian Kesehatan Republik Indonesia; 2016.

2. Depkes RI. Pedoman Dasar Dispensing Steril: Pedoman Dasar Teknik Aseptis. Jakarta: Departemen Kesehatan Republik Indonesia; 2009.

3. Stucki C., Sautter A.M., Favet J., Bonnabry P. Microbial Contamination of Syringes During Preparation: The Direct Influence of Environmental Cleanliness and Risk Manipulations on End-product Quality. Am J Health Syst Pharm. 2009; 66 (22): 2032-2036.

4. Allen J.L., Okeke C.C. Basics of Compounding; Considerations for Implementing United States Pharmacopeia Chapter 797 Pharmaceutical Compounding-Sterile Preparations, Part 13. Int J Pharm Compd. 2009; 13 (3): 234-238.

5. Austin P.D., Elia M.A. Systematic Review and Meta-Analysis of the Risk of Microbial Contamination of Aseptically Prepared Doses in Different Environments. J Pharm Pharm Sci. 2009; 12 (2): 233-242.

6. Dina C.A.P., Sri H.Y. Evaluasi Peracikan Injeksi Seftriakson di Salah Satu Rumah Sakit Swasta di Semarang. Jurnal Farmasi Klinik Indonesia. 2018; 7 (3): 143-153.
7. Melviya, Putri D.C.A., Yuliani S.H. Evaluasi Peracikan Sediaan Steril untuk Pasien Pediatri Rawat Inap di Rumah Sakit "X" Kota Semarang, Indonesia. Jurnal Manajemen dan Pelayanan Farmasi (JMPF). 2018; 8 (3): 128-135.

8. Westbrook J.I., Rob M.I., Woods A., Parry D. Errors in the Administration of Intravenous Medications in Hospital and the Role of Correct Procedures and Nurse Experience. BMJ Qual Saf. 2011; 20 (12): 1027-1034.

9. Grissinger M. Reducing Errors with Injectable Medications. Pharm Ther. 2010; 35 (8): 428-451.

10. Hidayanti E. Pelayanan Farmasi Klinis di Rumah Sakit X Tahun 2017. Skripsi. Universitas Islam Negeri Syarif Hidayatullah Jakarta; 2017.

11. Depkes RI. Peraturan Pemerintah Republik Indonesia Nomor 51 Tahun 2009 tentang Pekerjaan Kefarmasian. Jakarta: Departemen Kesehatan Republik Indonesia; 2009.

12. Aronson J.K. Medication Errors: What They Are, How They Happen, and How to Avoid Them. QJM. 2009; 102 (8): 513-521.

13. Perwitasari D. A., Abror J., Wahyuningsih I. Medication Errors in Outpatients of A Government Hospital in Yogyakarta Indonesia. International Journal of Pharmaceutical Sciences Review and Research. 2010; 1 (1): 810.

14. Salmani N., Fallah T.B. Frequency, Type and Causes of Medication Errors in Pediatric Wards of Hospitals in Yazd, the Central of Iran. International Journal Pediatric. 2016; 4 (9): 34753487.

15. Pandini I.P. Profil Pencampuran Sediaan Steril Injeksi di Rumah Sakit Umum Daerah Cilacap Tahun 2016. Skripsi. Univ Muhammadiyah Purwokerto; 2016. 